DOI 10.34883/PI.2021.7.4.014

UDC 616-006+34:577.2

Andriiaka A.

Shupyk National Healthcare University of Ukraine, Kyiv, Ukraine

Андрияка А.A.

Национальный университет охраны здоровья Украины имени П.Л. Шупика, Киев, Украина

\title{
Optimization of Secondary Metabolic Disorders and Treatment Tactics in Patients with Anemia of Malignant Neoplasm in Colorectal Cancer
}

\author{
Оптимизация диагностики вторичных метаболических \\ нарушений и лечебной тактики у пациентов с анемией \\ злокачественного новообразования при колоректальном раке
}

Abstract

Colorectal cancer is one of the most common oncological diseases, therefore, the study of this problem is an important issue in clinical practice. This problem becomes especially urgent in case of the formation of anemic syndrome in patients, which causes the emergence of a mutual burden syndrome and increases the risks for a patient. The progressive nature of anemia in colorectal cancer is accompanied by secondary metabolic disorders. The material for the study was the blood plasma of 445 patients ( 228 men and 217 women). Among them, 53 patients ( 31 women and 22 men) with iron deficiency anemia (IDA) were examined and included in the first observation group (I) and 392 patients (206 men (52.55\%) and 186 women (47.45\%)) with colorectal cancer (CRC) whose course of the underlying disease was burdened with anemia in neoplastic disease (AND) were included in the second observation group (II). Among the patients in the second (II) observation group, there were 222 individuals ( 119 men and 103 women) with malignant neoplasms of the colon (ICD-10 code: C.18), 29 individuals (16 men and 13 women) with malignant neoplasms of the rectosigmoid junction (ICD-10 code: C.19), 138 individuals (82 men and 56 women) with malignant neoplasms of the rectum (code ICD-10 C.20) and 3 patients ( 2 men and 1 woman) with malignant neoplasms of the anus (ICD-10 code: C.21). The age of the examined patients was from 22 to 79 years. The mean age of the patients was $(63.3 \pm 1.2)$ years. The plasma level of free fraction of heparin (FHN) of the examined patients was determined using the photocolorimetric method on photoelectric colorimeter FEC 56-M after its preliminary isolation by electrophoretic method according to the appropriate procedure (B.V. Mykhailychenko, S.V. Vydyborets (2000)). The plasma level of free fractions of histamine (FH) and serotonin (FS) of the examined patients was studied using the method of fluorometric analysis on the analyzer "BIAN-130"-"BIAN-100" according to the procedure of B.V. Mykhailychenko, S.V. Vydyborets (1999).

It was found that prior to the initiation of treatment in patients with AMN, regardless of the course of CRC, there was a significant increase in the plasma level of FHN, FH, FS $(p<0.001)$; the ratio of FH:FS was also changed in comparison with the values in the control group $(p<0.05)$, which indicated both an increased release of heparin, histamine and serotonin from the depot, and an impaired inactivation processes of these biologically active substances.

Currently, the main methods to treat anemia in oncological diseases, in particular, caused by 
chemotherapy, is the transfusion of media containing erythrocytes and/or the administration of preparations of erythropoietin which stimulate erythropoiesis in combination (or without) with iron preparations for parenteral (intravenous) administration.

Considering all of the above and the quite obvious reasons, namely, the secondary metabolic disorders of serotonin, histamine, heparin which manifested by a significant increase in their plasma level of patients with AMN in CRC, we suggested the need to use a medicinal product in a complex of therapeutic measures which can cause antihypoxic, membrane stabilizing and anti-edema action. Anemia in neoplastic disease in colorectal cancer is accompanied by significant changes in the metabolism of biologically active substances - free fractions of heparin, histamine, serotonin, and the ratio of free histamine to serotonin. It was correctly concluded that in addition to the baseline therapy the administration of arginine glutamate which causes both antihypoxic and membranestabilizing action, reliably contributes to the normalization of secondary metabolic disorders of histamine, serotonin and heparin metabolism in anemia in neoplastic disease in patients with rectal cancer.

Keywords: colorectal cancer, anemia in neoplastic disease, free histamine, free serotonin, free heparin, blood plasma.

\section{Резюме}

Колоректальный рак является одним из наиболее распространенных онкологических заболеваний. Исследование данной проблемы является важным вопросом в клинической практике. Особенную актуальность эта проблема приобретает в случае формирования у пациентов анемического синдрома, что влечет за собой возникновение синдрома взаимного утяжеления заболеваний и увеличивает риски для пациента. Прогрессирующий характер анемии при колоректальном раке сопровождается вторичными метаболическими нарушениями.

Материалом для исследования служила плазма крови 445 пациентов (228 мужчин и 217 женщин), среди которых обследовано 53 пациента (31 женщина и 22 мужчины) с железодефицитной анемией (ЖДА), они составили первую (I) группу наблюдения, и 392 пациента (206 мужчин $(52,55 \%)$ и 186 женщин $(47,45 \%))$ с колоректальным раком (КРР), течение основного заболевания у которых отягощалось АЗН (вторая (II) группа наблюдения). Среди пациентов, которые составили вторую (II) группу наблюдения, было 222 человека (119 мужчин и 103 женщины) со злокачественными новообразованиями ободочной кишки (шифр МКБ-10 International Classification of Diseases (ICD) under the code C.18), 29 лиц (16 мужчин и 13 женщин) со злокачественными новообразованиями ректосигмоидного отдела (шифр МКБ-10 С.19), 138 пациентов (82 мужчины и 56 женщин) со злокачественными новообразованиями прямой кишки (шифр МКБ-10 С.20) и 3 пациента (2 мужчин и 1 женщина) со злокачественными новообразованиями анального канала (шифр МКБ-10 С.21). Возраст обследованных - от 22 до 79 лет. Средний

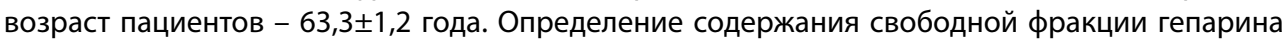
(СГП) в плазме крови осуществляли фотоколориметрическим методом на ФЕК 56-М после предварительного его выделения электрофоретическим путем по соответствующей методике (Б.В. Михайличенко, С.В. Выдыборец (2000)). Исследование содержания свободных фракций гистамина (СГ) и серотонина (СС) в плазме крови осуществляли методом флуориметрического анализа на анализаторе «БИАН-130»-«БИАН-100» по методике Б.В. Михайличенко, С.В. Выдыборца (1999).

Установлено, что до начала лечения у пациентов с АЗН независимо от течения при КРР имело место достоверное увеличение показателей содержания СГП, СГ, СС в плазме крови $(\mathrm{p}<0,001)$, также нарушалось соотношение СГ:СС по сравнению со значениями в группе контроля $(\mathrm{p}<0,05)$, что свидетельствовало как об усиленном высвобождении гепарина, гистамина и серотонина из депо, так и о нарушении процессов инактивации изученных биологически активных веществ. 
На сегодняшний день основными методами лечения анемии при онкологических заболеваниях, в частности той, что обусловлена химиотерапией, являются трансфузии эритроцитосодержащих сред и/или назначение препаратов эритропоэтина в комбинации (или без) с препаратами железа для парентерального (внутривенного) введения.

Учитывая все вышеизложенное причины, а именно выявленные нами вторичные нарушения обмена серотонина, гистамина, гепарина, что проявлялось достоверным повышением их содержания в плазме крови пациентов с АЗН при КРР, мы допустили необходимость применения в комплексе лечебных мероприятий препарата с антигипоксическим, мембраностабилизирующим, противоотечным действием.

АЗН при КРР сопровождается достоверными изменениями обмена биологически активных веществ - свободных фракций гепарина, гистамина, серотонина, показателя соотношения содержания свободного гистамина к серотонину.

Сделан вывод, что назначение к базисной терапии дополнительно аргинина глутамата, который действует как антигипоксант, так и мембраностабилизатор, достоверно нормализует вторичные метаболические нарушения содержания гистамина, серотонина и гепарина в плазме крови при АЗН у пациентов с КРР.

Ключевые слова: колоректальный рак, анемия злокачественного новообразования, свободный серотонин, свободный гепарин, свободный гистамин, плазма крови.

\section{- INTRODUCTION}

Anemia is one of the most frequent complications of cancer [1, 2]. It occurs both as a result of the onset, development and progression of the tumour process, and cytostatic and/or radiation therapy, which is used to treat cancer, the presence of hemolysis, splenomegaly, hemorrhagic syndrome, hemodilution, ineffective erythropoiesis, impaired regulation of iron metabolism in the patient's body, the key link of which is now considered to be changes in the hepcidin synthesis [3]. This type of anemia is called anemia in neoplastic disease (AND), and the nosological form of this anemia is included in the headings of the International Classification of Diseases (ICD) under the code D63.0. It is believed that an essential link in the AND pathogenesis is the absence of a compensatory increase in the rate of erythrocyte production, as well as a negative effect on the bone marrow (BM) of cytostatic drugs [4-6].

Long-term studies of the causes of tumours have led to the conclusion that tumour progression is the result of loss of control over cell replication due to mutation, after which the cell has an inherent potential for uncontrolled proliferation [1, 2].

Until now, there is a debate about whether metabolic changes are the primary factor triggering carcinogenesis, or the tumour transformation of cells initiated due to other reasons triggers pathological variants of cell metabolism. But the fact of the strict dependence of tumour cells on the supply of ATP as a result of intense glycolysis remains such that there is no doubt. Tumour cells are metabolically heterogeneous, that is, they are able to change metabolism to adapt to existence in conditions of competition for energy substances with cells of the normal microenvironment. It is known that different types of tumour cells can function by different bioenergetic mechanisms, for example, glycolysis and phosphorylation [7, 8]. In addition to glucose, tumour cells are able to metabolize alternative energy sources - 
fatty acids and amino acids. The mechanisms of regulation of these processes have not yet been sufficiently studied.

Anemia is accompanied by the development of hemic hypoxia, which in turn causes a wide range of metabolic disorders characteristic of the common pathophysiological process - hypoxia, in particular, excessive release of histamine, serotonin, heparin (the metabolism of which is closely related) [9-12].

Glutathione system in managing cancer patients is has been actively studies for over three decades [13]. Glutathione (y-L-glutamyl-L-cysteinylglycine) is a tripeptide containing in living organisms which plays multiple roles. Thereare two forms (reduced-GSH) and oxidized (glutathionedisulfideGSSG) which are available in all cellular structures. Its major portion is contained in cytoplasm (85\%) and minor (10-15\%) - in mitochondria and plasmatic reticulum [14]. The main reservoir of GSH in mammals is liver, which releases its significant amounts in blood and bile. Glutathione system includes three enzymes - glutathione peroxidase, glutathione transferase and glutathione reductase. It is the only system in the body which can be involved in three lines of antioxidative protection of four existing. Control of intracellular glutathione homeostasis is a complex process taking place due to its synthesis, consuming and degradation. Cellular GSH is de novo synthesised from amino acids such as glutamate, cysteine, glycine; it is reduced from GSSH with glutathione peroxidase and consumption of extracellular glutathione by the cell. Oxidized glutathione which activates glutathione system enzymes in cytosol, microsomes and mitochondria is the most reactive. Increased GSH levels are registered in many tumours which make them more resistant to chemotherapy [15]. GSH as an antioxidant due to the presence of the thiol group in cysteine residue. The other variant of GSH action is a direct interaction with reactive oxygen or nitrogen species. Furthermore, GSH acts as a cofactor for different enzymes.

Reactive oxygen species such as $\mathrm{H}_{2} \mathrm{O}_{2}, \mathrm{O} 2-, \mathrm{OH}$ - and others are considered as one of the main triggers of tumour process initiation and progress due to their ability to promote unstable genome and activate signal pathways. Synthesis of reactive oxygen species is a physiological process for aerobic cells. Action of the stressors on the cell is accompanied by increase in their production. Physiologically active levels of the reactive oxygen species are mediators of important intercellular signal pathways. Oxygen hyperproduction results in cell damage and its death. Oxidative stress plays a role in developing and progressing malignancies which gives the grounds to consider antioxidative therapy as the preventive measure. On the other side, pro-oxidative therapy, chemotherapeutic agents, ionising radiation are widely used in the clinical practice and are based on the view that additional oxidative exposure should induce collapse of anti-oxidative system and is accompanied by cell death. However, as suggested by the negative results of such an approach to many tumours, in particular those with hyperexpression of antioxidants that finally is accompanied by the development of resistance to them [15]. To prevent such a phenomena, there is an adaptative mechanism of response which involves compensatory response of antioxidative systems and achievement of redox homeostasis. Glutathione plays important protective role in terms of different forms of cell death, including apoptosis, necrosis, ferroptosis, autophagy [16]. Glutathione metabolism 
in tumour cells is disturbed. Their level of intracellular glutathione is significantly higher versus normal cells. Correlation between the increased intracellular glutathione level and resistance to pro-oxidative chemotherapy was shown $[17,18]$. Reactive oxygen species are the promoters of tumour process initiation via mutagenesis induction and possibly activation of signal pathways, which are the promoters of proliferation, surveillance and resistance to stress factors. On the other side, reactive oxygen species hold down tumour cells growth resulting in fatal oxidative stress. Therefore, antioxidants, including GSH, may play a leading role due to damage of reactive oxygen species and/or regulation of redox processes [19].

In addition to the direct effect on detoxification processes, GSH interacts with multiple signal pathways such as NK1, MAPK, TRAF2-ASK1, p38, p53, Trx etc. Variants of their interaction have been studied enough, and their detailed description is provided in various publications. Glutathione system still attracts attention of investigators as a potential target for inhibition of tumour progression and overcoming of tumour resistance to chemotherapy.

Theoretically, the justification of the strategy for the prevention of malignancies is the use of antioxidants or stimulation of cellular antioxidant activity. However findings of the experimental studies in this matter are questionable. Increased glutathione levels were found to be associated with proliferation of both normal and malignant cells.

\section{- PURPOSE}

The purpose of the work is to improve the efficacy of AND treatment in $C R C$ by improving the drug therapy regimen with the use of pathogenetically targeted correction of disorders identified on the basis of a comprehensive study of biochemical parameters of patients' plasma level of free fractions of serotonin, histamine, heparin.

\section{- MATERIALS AND METHODS}

This clinical study was conducted on the basis of the Kyiv Regional Oncological Dispensary. The material for the study was the blood plasma of 445 patients ( 228 men and 217 women). Among them, 53 patients (31 women and 22 men) with iron deficiency anemia (IDA) were examined and included in the first observation group (I) and 392 patients (206 men (52.55\%) and 186 women (47.45\%)) with colorectal cancer (CRC) whose course of the underlying disease was burdened with anemia in neoplastic disease (AND) were included in the second observation group (II). Among the patients in the second (II) observation group, there were 222 individuals (119 men and 103 women) with malignant neoplasms of the colon (ICD10 code: C.18), 29 individuals (16 men and 13 women) with malignant neoplasms of the rectosigmoid junction (ICD-10 code: C.19), 138 individuals (82 men and 56 women) with malignant neoplasms of the rectum (code ICD10 C.20) and 3 patients ( 2 men and 1 woman) with malignant neoplasms of the anus (ICD-10 code: C.21). The age of the examined patients was from 22 to 79 years. The mean age of the patients was (63.3 \pm 1.2$)$ years. Anemic syndrome was present in the examined patients upon admission to the hospital. The presence of colorectal cancer of Stage III-IV according to S.E. Dukes (1956) was determined histochemically. All patients were examined prior to the initiation of any treatment. 
The severity of anemia was determined according to the criteria proposed by the National Cancer Institute (USA) and was allocated as: mild anemia - hemoglobin 10-12 g/dL; moderate anemia - 8-10 g/dL; severe anemia - 6.5-8 g/dL; life-threatening anemia - below $6.5 \mathrm{~g} / \mathrm{dL}$. Among patients with IDA, 19 people were diagnosed with mild IDA, 15 people with moderate IDA, 11 people - with severe IDA and 8 people - with lifethreatening IDA. Mild AND in CRC was diagnosed in 172 patients (92 men and 80 women), moderate - in 114 patients ( 66 men and 48 women), severe in 78 people ( 32 men and 48 women) and life-threatening - in 28 patients (16 men and 12 women). The control group consisted of 50 primary blood donors who had no history of oncological or chronic inflammatory diseases.

The plasma level of free fraction of heparin ( $\mathrm{FHN}$ ) of the examined patients was determined using the photocolorimetric method on photoelectric colorimeter FEC 56-M after its preliminary isolation by electrophoretic method according to the appropriate procedure [20]. The plasma level of free fractions of histamine (FH) and serotonin (FS) of the examined patients was studied using the method of fluorometric analysis on the analyzer "BIAN-130"-"BIAN-100" according to the procedure of B.V. Mykhailychenko, S.V. Vydyborets (1999) [21].

Patients with mild and moderate anemia $(n=286)$ received basic therapy with iron preparations intravenously under the control of peripheral blood parameters; in addition to the administration of iron preparations patients with severe AND $(n=78)$ received erythropoietin preparation; and in addition to iron and erythropoietin preparations patients with life-threatening anemia $(n=28)$ received transfusions of erythrocytes. Depending on the therapy, some patients (observation group IIA) with AND in CRC, in addition to the basic therapy, received arginine glutamate, which is well-known and has proven itself as a hepatoprotector, which is positive in this clinical situation and due to its composition causes both antihypoxic and membrane stabilizing action. The study results were processed using the methods of variation statistics by calculating the Student's t-test $(p<0.05)$.

\section{- RESULTS AND DISCUSSION}

Data on the parameters of the plasma level of $\mathrm{FHN}, \mathrm{FH}, \mathrm{FS}$ of primary blood donors (control group) are given in Table 1.

Table 1

Plasma level of FHN, FH, FS of healthy subjects ( $M \pm m$ )

\begin{tabular}{|l|l|l|l|l|}
\hline $\begin{array}{l}\text { Studied parameter, } \\
\text { unit of measurement }\end{array}$ & $\begin{array}{l}\text { Total } \\
(\mathbf{n = 5 0 )}\end{array}$ & $\begin{array}{l}\text { Men } \\
(\mathbf{n = 2 9 )}\end{array}$ & $\begin{array}{l}\text { Women } \\
(\mathbf{n = 2 1 )}\end{array}$ & $\begin{array}{l}\text { Significance } \\
\text { of differences (p) }\end{array}$ \\
\hline Level of FHN $(\mu \mathrm{g} / \mathrm{g})$ & $21.28 \pm 0.51$ & $21.41 \pm 0.75$ & $20.96 \pm 1.15$ & $\mathrm{p}>0.1$ \\
\hline $\begin{array}{l}\text { Level of FH } \\
(\mathrm{nmol} / \mathrm{g})\end{array}$ & $1.45 \pm 0.14$ & $1.45 \pm 0.16$ & $1.46 \pm 0.30$ & $\mathrm{p}>0.1$ \\
\hline $\begin{array}{l}\text { Level of FS } \\
(\mathrm{nmol} / \mathrm{g})\end{array}$ & $0.59 \pm 0.05$ & $0.59 \pm 0.09$ & $0.57 \pm 0.07$ & $\mathrm{p}>0.1$ \\
\hline $\begin{array}{l}\text { Ratio } \\
\text { FH: FS }\end{array}$ & $2.78 \pm 0.25$ & $2.79 \pm 0.30$ & $2.76 \pm 0.49$ & $\mathrm{p}>0.1$ \\
\hline
\end{tabular}

Note: $p$ - the significance of differences between values depending on gender. 
The obtained data of biochemical parameters of blood on the plasma level of FHN, FH, FS of primary donors can be used as controls when conducting a comparative analysis.

The biochemical values of the plasma level of $\mathrm{FHN}, \mathrm{FH}, \mathrm{FS}$ prior to the initiation of treatment in patients with mild AND in CRC are given in Table 2.

As can be seen from Table 2 prior to the initiation of treatment in patients with mild $A D N$ in $C R C$, there was a significant increase in the plasma level of $\mathrm{FHN}, \mathrm{FH}, \mathrm{FS}(\mathrm{p}<0,001)$; the ratio of $\mathrm{FH}: \mathrm{FS}$ was also changed in comparison with the values in the control group $(p<0,05)$, which indicated both an increased release of heparin, histamine and serotonin from the depot, and an impaired inactivation processes of these biologically active substances.

The biochemical values of the plasma level of $\mathrm{FHN}, \mathrm{FH}, \mathrm{FS}$ prior to the initiation of treatment in patients with moderate AND in CRC are given in Table 3.

Table 2

The plasma level of FHN, FH, FS of patients with AND in CRC (mild course) and determination of their ratio in the period before the initiation of treatment $(M \pm m)$

\begin{tabular}{|l|l|l|l|l|}
\hline $\begin{array}{l}\text { Studied parameter, } \\
\text { unit of measurement }\end{array}$ & $\begin{array}{l}\text { Total } \\
(\mathbf{n = 1 7 2 )}\end{array}$ & $\begin{array}{l}\text { Men } \\
(\mathbf{n = 9 2 )}\end{array}$ & $\begin{array}{l}\text { Women } \\
(\mathbf{n = 8 0 )}\end{array}$ & $\begin{array}{l}\text { Significance } \\
\text { of differences (p) }\end{array}$ \\
\hline Level of FHN $(\mu \mathrm{g} / \mathrm{g})$ & $26.04 \pm 0.35$ & $26.17 \pm 0.61$ & $26.09 \pm 0.41$ & $\begin{array}{l}\mathrm{p}_{1}>0.1 \\
\mathrm{p}_{2}<0.001\end{array}$ \\
\hline $\begin{array}{l}\text { Level of FH } \\
(\mathrm{nmol} / \mathrm{g})\end{array}$ & $3.24 \pm 0.77$ & $3.35 \pm 0.39$ & $3.17 \pm 0.52$ & $\begin{array}{l}\mathrm{p}_{1}>0.1 \\
p_{2}<0.001\end{array}$ \\
\hline $\begin{array}{l}\text { Level of FS } \\
(\mathrm{nmol} / \mathrm{g})\end{array}$ & $1.59 \pm 0.04$ & $1.65 \pm 0.23$ & $1.54 \pm 0.08$ & $\begin{array}{l}p_{1}>0.1 \\
p_{2}<0.001\end{array}$ \\
\hline $\begin{array}{l}\text { Ratio } \\
\text { FH:FS }\end{array}$ & $2.04 \pm 0.03$ & $2.03 \pm 0.08$ & $2.06 \pm 0.07$ & $\begin{array}{l}p_{1}>0.1 \\
p_{2}<0.001\end{array}$ \\
\hline
\end{tabular}

Notes: $p_{1}$ - the significance of differences between values depending on gender; $p_{2}$ - the significance of differences between values in comparison with the control group.

Table 3

The plasma level of FHN, FH, FS of patients with AND (moderate course) in CRC and determination of their ratio in the period before the initiation of treatment $(M \pm m)$

\begin{tabular}{|l|l|l|l|l|}
\hline $\begin{array}{l}\text { Studied } \\
\text { parameter, unit of } \\
\text { measurement }\end{array}$ & $\begin{array}{l}\text { Total } \\
(\mathbf{n = 1 1 4 )}\end{array}$ & $\begin{array}{l}\text { Men } \\
(\mathbf{n = 6 6 )}\end{array}$ & $\begin{array}{l}\text { Women } \\
(\mathbf{n = 4 8 )}\end{array}$ & $\begin{array}{l}\text { Significance } \\
\text { of differences (p) }\end{array}$ \\
\hline Level of FHN $(\mu \mathrm{g} / \mathrm{g})$ & $28.69 \pm 0.39$ & $28.17 \pm 0.61$ & $3.74 \pm 0.41$ & $\begin{array}{l}\mathrm{p}_{1}>0.1 \\
\mathrm{p}_{2}<0.001 \\
\mathrm{p}_{3}<0.001\end{array}$ \\
\hline $\begin{array}{l}\text { Level of FH } \\
(\mathrm{nmol} / \mathrm{g})\end{array}$ & $3.84 \pm 0.75$ & $3.85 \pm 0.64$ & $3 \pm 0.52$ & $\begin{array}{l}\mathrm{p}_{1}>0.1 \\
\mathrm{p}_{2}<0.001 \\
\mathrm{p}_{3}<0.001\end{array}$ \\
\hline $\begin{array}{l}\text { Level of FS } \\
\text { (nmol/g) }\end{array}$ & $1.68 \pm 0.02$ & $1.75 \pm 0.21$ & $1.59 \pm 0.07$ & $\begin{array}{l}\mathrm{p}_{1}>0.1 \\
\mathrm{p}_{2}<0.001 \\
\mathrm{p}_{3}<0.001\end{array}$ \\
\hline $\begin{array}{l}\text { Ratio } \\
\text { FH:FS }\end{array}$ & $2.29 \pm 0.04$ & $2.20 \pm 0.08$ & $2.41 \pm 0.07$ & $\begin{array}{l}\mathrm{p}_{1}>0.1 \\
\mathrm{p}_{2}<0.001 \\
\mathrm{p}_{3}<0.001\end{array}$ \\
\hline
\end{tabular}

Notes: $p_{1}$ - the significance of differences between values depending on gender; $p_{2}$ - the significance of differences between values in comparison with the control group; $p_{3}$ - the significance of differences between values in comparison with the group of patients with mild AND. 
As can be seen from the data given in Table 3, there were more significant impairments in the plasma level of the substances studied in patients with moderate AND in CRC in comparison with patients with mild anemia.

The biochemical values of the plasma level of $\mathrm{FHN}, \mathrm{FH}, \mathrm{FS}$ prior to the initiation of treatment in patients with severe AND in CRC are given in Table 4.

As can be seen from Table 4 prior to the initiation of treatment in patients with severe ADN in CRC, there was a significant increase in the plasma level of $\mathrm{FHN}, \mathrm{FH}, \mathrm{FS}$ compared with the control group and patients with mild and moderate ADN; the ratio of FH:FS was also changed $(p<0,001)$, which indicated both more significant impairments of heparin, histamine and serotonin release from the depot, and an impaired inactivation processes of these biologically active substances.

The biochemical values of the plasma level of $\mathrm{FHN}, \mathrm{FH}, \mathrm{FS}$ prior to the initiation of treatment in patients with life-threatening AND in CRC are given in Table 5.

As can be seen from Table 5 prior to the initiation of treatment in patients with life-threatening ADN in CRC, there was a significant increase in the plasma level of FHN, FH, FS compared with the control group and patients with moderate and severe ADN; the ratio of FH:FS was also changed $(p<0.001)$, which indicated both more significant impairments of heparin, histamine and serotonin release from the depot, and impaired inactivation processes of these biologically active substances. Attention is drawn to the fact that the FH:FS ratio in this group of patients decreased in comparison with its values in patients with the severe course.

\section{Table 4}

The plasma level of FHN, FH, FS of patients with AND (severe course) in CRC and determination of their ratio in the period before the initiation of treatment $(M \pm m)$

\begin{tabular}{|l|l|l|l|l|}
\hline $\begin{array}{l}\text { Studied } \\
\text { parameter, unit of } \\
\text { measurement }\end{array}$ & $\begin{array}{l}\text { Total } \\
(\mathbf{n = 7 8 )}\end{array}$ & $\begin{array}{l}\text { Men } \\
(\mathbf{n = 3 2 )}\end{array}$ & $\begin{array}{l}\text { Women } \\
(\mathbf{n = 4 8 )}\end{array}$ & $\begin{array}{l}\text { Significance } \\
\text { of differences (p) }\end{array}$ \\
\hline Level of FHN $(\mu \mathrm{g} / \mathrm{g})$ & $36.49 \pm 0.37$ & $37.01 \pm 0.64$ & $36.14 \pm 0.15$ & $\begin{array}{l}\mathrm{p}_{1}>0.1 \\
\mathrm{p}_{2}<0.001 \\
\mathrm{p}_{3}<0.001 \\
\mathrm{p}_{4}<0.001\end{array}$ \\
\hline $\begin{array}{l}\text { Level of FH } \\
\text { (nmol/g) }\end{array}$ & $5.11 \pm 0.15$ & $5.15 \pm 0.64$ & $5.03 \pm 0.51$ & $\begin{array}{l}\mathrm{p}_{1}>0.1 \\
\mathrm{p}_{2}<0.001 \\
\mathrm{p}_{3}<0.001 \\
\mathrm{p}_{4}<0.001\end{array}$ \\
\hline $\begin{array}{l}\text { Level of FS } \\
\text { (nmol/g) }\end{array}$ & & & & $\begin{array}{l}\mathrm{p}_{1}>0.1 \\
\mathrm{p}_{2}<0.001 \\
\mathrm{p}_{3}<0.001 \\
\mathrm{p}_{4}<0.001\end{array}$ \\
\hline & $1.64 \pm 0.02$ & $1.71 \pm 0.11$ & $1.51 \pm 0.08$ & \\
\hline $\begin{array}{l}\text { Ratio } \\
\text { FH:FS }\end{array}$ & & & & $\begin{array}{l}\mathrm{p}_{1}>0.1 \\
\mathrm{p}_{2}<0.001 \\
\mathrm{p}_{3}<0.001 \\
\mathrm{p}_{4}<0.001\end{array}$ \\
\hline
\end{tabular}

Notes: $p_{1}$ - the significance of differences between values depending on gender; $p_{2}$ - the significance of differences between values in comparison with the control group; $\mathrm{p}_{3}$ - the significance of differences between values in comparison with the group of patients with mild AND; $p_{4}$ - the significance of differences between values in comparison with the group of patients with moderate AND. 
Table 5

The plasma level of FHN, FH, FS of patients with AND (life-threatening course) in CRC and determination of their ratio in the period before the initiation of treatment $(M \pm m)$

\begin{tabular}{|c|c|c|c|c|}
\hline $\begin{array}{l}\text { Studied } \\
\text { parameter, unit of } \\
\text { measurement }\end{array}$ & $\begin{array}{l}\text { Total } \\
(n=392)\end{array}$ & $\begin{array}{l}\text { Men } \\
(n=206)\end{array}$ & $\begin{array}{l}\text { Women } \\
(n=186)\end{array}$ & $\begin{array}{l}\text { Significance } \\
\text { of differences (p) }\end{array}$ \\
\hline Level of FHN $(\mu \mathrm{g} / \mathrm{g})$ & $41.03 \pm 1.31$ & $39.97 \pm 1.69$ & $42.19 \pm 2.43$ & $\begin{array}{l}\mathrm{p}_{1}>0.1 \\
\mathrm{p}_{2}<0.001 \\
\mathrm{p}_{3}<0.001 \\
\mathrm{p}_{4}<0.001 \\
\mathrm{p}_{5}<0.001\end{array}$ \\
\hline $\begin{array}{l}\text { Level of FH } \\
(\mathrm{nmol} / \mathrm{g})\end{array}$ & $5.46 \pm 0.48$ & $5.45 \pm 0.39$ & $5.47 \pm 0.59$ & $\begin{array}{l}\mathrm{p}_{1}>0.1 \\
\mathrm{p}_{2}<0.001 \\
\mathrm{p}_{3}<0.001 \\
\mathrm{p}_{4}<0.001 \\
\mathrm{p}_{5}<0.001\end{array}$ \\
\hline $\begin{array}{l}\text { Level of FS } \\
(\mathrm{nmol} / \mathrm{g})\end{array}$ & $2.49 \pm 0.19$ & $2.45 \pm 0.29$ & $2.44 \pm 0.07$ & $\begin{array}{l}p_{1}>0.1 \\
p_{2}<0.001 \\
p_{3}<0.001 \\
p_{4}<0.001 \\
p_{5}<0.001\end{array}$ \\
\hline $\begin{array}{l}\text { Ratio } \\
\text { FH:FS }\end{array}$ & $2.19 \pm 0.07$ & $2.22 \pm 0.05$ & $2.24 \pm 0.08$ & $\begin{array}{l}p_{1}>0.1 \\
p_{2}<0.001 \\
p_{3}<0.001 \\
p_{4}<0.001 \\
p_{5}<0.001\end{array}$ \\
\hline
\end{tabular}

Notes: $p_{1}$ - significance of differences between values depending on gender; $p_{2}$ - significance of differences between values in comparison with the control group; $p_{3}$ - significance of differences between values in comparison with the group of patients with mild AND; $\mathrm{p}_{4}$ - significance of differences between values in comparison with the group of patients with moderate AND; $\mathrm{p}_{5}$ - significance of differences between values in comparison with the group of patients with severe AND.

It is known that there is a serotonergic regulation of the gastrointestinal motor function in the human body. The gastrointestinal motor function is an important component of the digestion process which ensures the uptake of food, its mechanical processing, movement along the alimentary canal in a strict sequence in accordance with the periods of chemical digestion of food ingredients in its segments. The large intestine, as an object of regulatory influence, carried out by serotonin, takes the leading place since the process of digestion in humans ends precisely in the distal colon.

Serotonin is one of the main intestinal neurotransmitters. A significant amount of serotonin is synthesized and accumulated in the mucosa of the large intestine. Serotonin is synthesized and deposited in enterochromaffin cells, the maximum content of which is found in the rectum and duodenum. Mechanical deformation of enterochromaffincells with an increase in pressure inside the intestine causes the release of serotonin, which is confirmed by an increase in its amount, which is released into the intestinal cavity. In this case, the release of serotonin is considered one of the intermediate stages in the action of various stimulating factors on the intestinal wall. Serotonergic neurons are widely represented in the enteric nervous system, in particular, in the Auerbach's plexus of the human intestine. Serotonergic preganglionic fibers are located mainly in the myenteric nervous plexus; a connection of this type of fibers with postganglionic neurons has been revealed. Serotonin-immunoreactive fibers form a plexus and can be traced to the circular muscle layer and submucosa of the intestine. 
Considering the role of serotonin in peristalsis, one should take into account its ability to stimulate the excitability of myenteric neurons. The effect of serotonin is mediated by the activation of the corresponding $5-\mathrm{HT}$ receptors. 5-HT 1A, 5-HT 3, 5-HT4 receptors are found on enteric neurons. Activation of receptors by serotonin stimulates the motor activity of the large intestine. Serotonin plays an important role in the regulation of afferent signals, motility and secretion in the digestive tract, and accordingly, disruption of biosynthesis, content, release and reuptake negatively affects the functions of the digestive tract. Serotonin is removed from the interstitial space by reuptake with the specialized transport protein SERT. The SERT transporter is characterized by a high affinity for serotonin, is a presynaptic protein that specializes in the removal of serotonin from the synaptic cleft. It is presented not only in central and peripheral neurons but also in intestinal epithelial cells and platelets. Serotonin binding systems are also found in the enteral sympathetic endings which release serotonin upon stimulation. It should be remembered that serotonin is not only a transmitter but also an important mediator of inflammation and immunity.

To date, the presence of 12 histamine derivatives has been discovered and identified in living organisms. Their presence is explained by the presence of two reactive centers in the histamine molecule: the nuclei of the amino group (NH-) and the side chain of the amino group $\left(\mathrm{NH}_{2}{ }^{-}\right)$, thanks to which there is a certain spectrum of histamine derivatives. The existence of a certain relationship between the conformation of the histamine molecule and its biological activity has been established. It is believed that the histamine molecule is only active when the side chain is completely bent and is in transform, and the $\mathrm{C}$ atoms are coplanar with the imidazole ring, which provides the maximum distance between the nitrogen of the imidazole ring and the nitrogen atom of the amino group. Substitution of hydrogen in the presence of nitrogen atoms makes histamine inactive to the receptor.

Histamine is a constituent part of almost all tissues, biological fluids and faeces of animals and humans. Most of all it is in the skin, tissues of the digestive tract, lungs, that is, in the tissues which are in maximum contact with the external environment. Most often, histamine is determined in blood, plasma, urine, saliva, cerebrospinal fluid, tissues, less often - hair, sweat, mucus of the nasal passages, bile. In the blood, histamine is localized mainly in basophilic and eosinophilic leukocytes. The normal blood level of histamine in human is $40-70 \mathrm{ng} / \mathrm{mL}$, and the plasma level $-1-2$ orders of magnitude lower.

In animals and humans, histamine is synthesized from food proteins during the decarboxylation of histidine with bacteria of the intestinal flora of the E. coli group, and partially, in small quantities, directly from food exogenously, and by intracellular decarboxylation of histidine with histidine decarboxylase - endogenously.

Histamine, released into the blood and tissues, is metabolized in three ways: deamination with diamine oxidase or histaminase with the formation of imidazole acid via 4-imidazolecarboxaldehyde; methylation with the formation of 1-methylhistamine or N-methylhistamine using the histamine$\mathrm{N}$-methyltransferase enzyme; acylation with the formation of 4-(betaacetylaminoethyl)imidazole using the acetylase enzyme (in bacteria, not detected in vertebrates). 
Histamine is a tissue hormone, a mediator in the nervous system, a stimulant and inhibitor of intracellular, tissue and organ transformations, as well as a pharmacological drug. The reactions caused by histamine often go beyond homeostasis and are accompanied by pathological disorders both in organs and in the body as a whole. Its presence in quantities exceeding the "pharmacological" ones often cause impairment in the normal vital functions. The toxic effect of histamine is enhanced by drugs such as monoaminooxidase inhibitors, alcohol and other biologically active amines.

The heparin synthesis in the human body mainly occurs in the cytoplasm of mast cells, where it can be in a free state or in the form of a heparinzinc-histamine complex. In the peripheral blood, the depot of heparin is neutrophilic leukocytes. Heparin is part of the sulfated polysaccharides of tissues and its specific gravity is up to $5 \%$. In response to various stimuli, in particular, hypoxia, heparin is released from the depot granules. At the same time, eosinophil chemotactic factor, histamine, serotonin, dopamine, proteases (tryptases and chymases) and so on are simultaneously released. Mast cells are able not only to synthesize but also to absorb heparin from the blood circulation and incorporate it in the granules, as well as glycogen, inulin, dextrin, carboxymethyl cellulose. Depending on the structural characteristics of the polysaccharide part of the heparin molecule, the manifestation of the relationship between the internal structures of labrocytes and polymers, which have penetrated to them, are different; with the help of non-fractional 35S-heparin, it was demonstrated that heparin, which is accumulated by mast cells of the connective cell type, with increased coagulant potential of the blood, is released from them into the blood circulation and is involved in the reactions of providing hemostasis. The release of heparin from mast cells occurs with endocytosis and exocytosis. As we have already noted, one of the factors which can initiate processes of mast cell degranulation is hypoxia.

Hypoxia is a typical pathological condition that always accompanies anemic syndrome. Of course, the assumption about the importance of pathophysiological changes in the plasma level of histamine, serotonin and heparin in patients with colorectal cancer accompanied by the development of anemia of neoplasm disease will be reasonable. In our opinion, special attention should be paid to the correction of the detected secondary metabolic disorders at the stage of preparing patients for further treatment. Since such a correction should be a separate stage in the patient's treatment.

Currently, the main methods to treat anemia in oncological diseases, in particular, caused by chemotherapy, is the transfusion of media containing erythrocytes and/or the administration of preparations of erythropoietin which stimulate erythropoiesis in combination (or without) with iron preparations for parenteral (intravenous) administration.

Considering all of the above and the quite obvious reasons, namely, the secondary metabolic disorders of serotonin, histamine, heparin which manifested by a significant increase in their plasma level of patients with AMN in CRC, we suggested the need to use a medicinal product in a complex of therapeutic measures which can cause antihypoxic, membrane stabilizing and anti-edema action. Since we did not find such works in the scientific literature available to us, it was decided on the basis of clarifying the state of serotonin, histamine, heparin metabolism in the blood plasma of patients with AND in CRC, to increase the treatment efficacy by improving the drug therapy regimen. 
Table 6

The plasma level of FHN, FH, FS of patients with AND in CRC after treatment with arginine glutamate use $(\mathrm{M} \pm \mathrm{m})$

\begin{tabular}{|l|l|l|l|}
\hline $\begin{array}{l}\text { Studied } \\
\text { Parameter, unit of measurement }\end{array}$ & $\begin{array}{l}\text { Patients of IA group } \\
(\mathbf{n = 1 8 0 )}\end{array}$ & $\begin{array}{l}\text { Patients of IB group } \\
(\mathbf{n = 2 1 2})\end{array}$ & $\begin{array}{l}\text { Significance } \\
\text { of differences (p) }\end{array}$ \\
\hline Level of FHN $(\mu \mathrm{g} / \mathrm{g})$ & $23.54 \pm 0.51$ & $27.83 \pm 0.51$ & $\begin{array}{l}p_{1}>0.1 \\
p_{2}<0.001 \\
p_{3}<0.05\end{array}$ \\
\hline Level of FH $(\mathrm{nmol} / \mathrm{g})$ & $1.74 \pm 0.18$ & $2.84 \pm 0.38$ & $\begin{array}{l}p_{1}>0.1 \\
p_{2}<0.001 \\
p_{3}<0.01\end{array}$ \\
\hline & & & $\begin{array}{l}p_{1}>0.1 \\
p_{2}<0.001 \\
p_{3}<0.05\end{array}$ \\
\hline Level of FS $(\mathrm{nmol} / \mathrm{g})$ & $1.21 \pm 0.10$ & $1.45 \pm 0.11$ & $\begin{array}{l}p_{1}>0.1 \\
p_{2}<0.001 \\
p_{3}<0.05\end{array}$ \\
\hline $\begin{array}{l}\text { Ratio } \\
\text { FH:FS }\end{array}$ & $1.43 \pm 0.04$ & $1.96 \pm 0.05$ & \\
\hline
\end{tabular}

Notes: $p_{1}$ - the significance of differences between values depending on gender; $p_{2}$ - the significance of differences between values in comparison with the control group; $p_{3}$ - the significance of differences between values of patients in IIA and IIB groups.

As we noted above, all patients with AND in CRC were divided into two subgroups depending on the inclusion of arginine glutamate, which causes both antihypoxic and membrane stabilizing action, in addition to the basic therapy. The following groups were formed: a group of patients who received the indicated drug (IIA ( $n=180,98$ men and 82 women) and a group of patients who received the basic therapy only (IIB $(n=212,108$ men and 104 women).

The safety study results of the arginine glutamate use in the treatment of patients with AND with CRC at the stage of preparation for further treatment are given in Table 6.

As can be seen from Table 6, after the inclusion of arginine glutamate, which was administered at the beginning of treatment at a dose of $0.25 \mathrm{~g}$ orally three times a day after a meal for 14 days, in concomitant therapy of patients from IIA group, the plasma level of FHN, FH, FS significantly decreased $(p<0.05)$ after 2 weeks and the FH:FS ratio in blood plasma normalized $(p<0.05)$, which was indirect evidence of reduced severity of intoxication syndrome in patients of IIA group.

\section{- CONCLUSIONS}

Anemia in neoplastic disease in colorectal cancer is accompanied by significant changes in the metabolism of biologically active substances free fractions of heparin, histamine, serotonin, and the ratio of free histamine to serotonin.

The main methods of treating anemia in cancer are the administration of iron preparations parenterally (intravenously), erythropoietin preparations, transfusion of erythrocyte-containing media.

The pathogenetically oriented method of treatment of patients with anemia in neoplasm disease in colorectal cancer has been improved and introduced into practice. It has a good perspective and consists of administration of a drug, which has an antioxidant, anti-edemic and membrane-stabilizing action, in the addition to the basic therapy. 
The administration of arginine glutamate, which causes both antihypoxic and membrane-stabilizing action, in addition to the baseline therapy reliably contributes to the normalization of secondary metabolic disorders of histamine, serotonin and heparin metabolism in anemia in neoplastic disease in patients with rectal cancer.

Conflict of interest. The authors of this study confirm that the research and publication of the results were not associated with any conflicts regarding commercial or financial relations with organizations and/or individuals who may have been related to the study, and interrelations of coauthor of the article. The authors declare no conflict of interest.

\section{- REFERENCES}

1. Berezhnaya NM, Chekhun VF. Immunologiya zlokachestvennogo rosta [Immunology of tumor growth]. Kyiv: Naukova dumka, 2005.792 p. (in Russian)

2. Berezhnaya NM. Semeystva interleykinov; biologiya i onkogenes [The families of interleukins: Biology and onkogenesis]. Kyiv: Naukova dumka, 2013. 576 p. (in Russian)

3. Vydyborets SV, Andriiaka AO. Fiziologichna rol gepsidinu jak zentralnogo regulyatora meabolizmu zaliza (oglyad literatury) [The physiological role of hepcidin as a central regulator of iron metabolism (literature review). Simejna medyzyna. Family medicine. 2017; 1(69): $154-157$.

4. American Cancer Society (2010) American Cancer Society: Cancer Facts and Figures 2010. Atlanta, GA:66-71.

5. World Cancer Research Fund International. Available at: http://www.wcrforg

6. Greer J.P., Arber D.A., Glader B. (eds.) Wintrobe's clinical hematology. Philadelphia: Lippincott Williams \& Wilkins, 2014. 2278 p.

7. Fedorenko ZP, Kolesnik OO, Gulak IO, Ryzhov AY, Sumkina OV. Kolorektalnyi rak v Ukraini: epidemiologichni ta organizatsijni aspekty problemy [Colorectal cancer in Ukraine: the epidemiological and organizational aspects of the problem]. Prakticna onkologia. Practical oncology. 2019; 2: 9-16. DOI: 10.22141/2663-3272.2.2.2019.176026.

8. Linchevskii OV, Kovaliov OO, Kolesnyk OO, Beznosenko AP. Zlojakisni novoutvorennja v Ukraini (analityko-statystychnyi dovidnyk) [Malignant neoplasms in Ukraine (analytical and statistical reference book)]. Praktycna onkologia. Practical Oncology, 2019; 2: 59-118. DOI: 10.22141/26633272.2.2.2019.176034

9. Luniova GG. (eds.) Klinichna biochimiia [Clinical Biochemistry]: Handbook. Kyiv: Atika, 2013. 1156 p. [Ukrainian]

10. Bublij Yu. Heparyn: fiziologitchna rol'i klinitchne znatchennia porushen vmistu [Heparin: physiological role and clinical meaning of the contens]. Ukrajinskij zhurnal gematologii i transfusiologii. 2013; 6(17): 5-10.

11. Martin AM, Young RL, LeongL, Rogers GB, Spencer NJ, Jessup CF, Keating DJ. The diverse metabolic roles of peripheral serotonin. Endocrinology, 2017; 5: 1049-1063.

12. Mauler M, Bode C, Duerschmied D. Platelet serotonin modulates immune functions. Hamostaseologie, 2016; 1: 11-16.

13. Balendiran GK, Dabur R, Fraser D. The role of glutathione in cancer. Cell Biochem. Funct. 2004; 22: 343-352.

14. Lu SC. Glutathione synthesis. Biochim. Biophys. Acta, 2013; 1830: 3143-3153.

15. Traverso N, Ricciarelli R, Nitti M, Marengo B, Furtaro AL, Pronzato MA, Marinari UM, Domenicotti C. Role of glutatione in cancer progression and chemoresistance. Oxid. Med. Cell. Longev. 2013: 972913.

16. Halem E, El Banna N, Huang ME. Multifaceted roles of glutathione and glutathione-based systems in carcinogenesis and anticancer drug resistance. Antioxid Redox Signal. Nov. 2017; 20; 27(15): 1217-1234.

17. Estrela JM, Ortega A, Obrador E. Glutathione in cancer biolgy and therapy. Crit. Rev. Clin. Lab. Sci. 2006; 43: 143-181.

18. Singh S. Cytoprotective and regulatory functions of glutathione-S-transferases in cancer cell proliferation and cell death. Cancer Chemother. Pharmacol. 2015; 75: 1-15.

19. Corso CR, Asso A. Glutathione system in animal model of solid tumors: from regulation to therapeutic target. Crit. Rev. Oncol. Hematol. 2018; Aug. 128: 43-57.

20. Mykhailychenko B, Vydyborets S. Metod kil'kisnogo vyznatshennia geparynu v biosubstratah [Method of quantative determination of heparin in biological speciments]. Laboratorna diagnostika, 2000; 4: 53-56.

21. Mikhailichenko BV, Vydyborets SV. Metod odnochasnogo fluorymetrychnogo vyznachennja biogennych aminiv v analizovanij probi biosubstratu [The metod of simultaneousfluorimetric assay of biogenic amines in biological speciments]. Laboratorna diagnostika, $1999 ; 2: 58-61$. 